\title{
Farmers' Capacity for Jatiluwih Agrotourism Management and Its Effects on Tourists' Satisfaction and Intention to Revisit
}

\author{
Tien Cathy Patricia ${ }^{1}$, I Gusti Ayu Oka Suryawardani' ${ }^{2}$ I Ketut Suamba ${ }^{1}$ \\ and Agung Suryawan Wiranatha ${ }^{2}$ \\ ${ }^{1}$ Agribusiness Study Program, Faculty of Agriculture, Udayana University \\ ${ }^{2}$ Centre of Excellence in Tourism, Udayana University \\ Corresponding Author: cathypatricia13@gmail.com
}

\begin{abstract}
ARTICLE INFO
Received

28 November 2019

Accepted

28 January 2020

Available online

01 March 2020

ABSTRACT

Capacity is the main element for farmers in achieving their goals. Farmer's Capacity consists elements of knowledge, attitude, and skills. With the increasing number of visits in Bali, especially Jatiluwih Agrotourism, farmers should be the subject of management so that they can fully enjoy the benefits of the visit. With the existence of agrotourism, agriculture and tourism can be a pair of harmonious sectors. Tourist's feedback on the satisfaction and intention to revisit can be an input in the effort to increasing the farmer's capacity in agrotourism management for its sustainability. This paper analyzes Farmer's Capacity for Jatiluwih Agrotourism Management and Its Influence toward Tourist's Satisfaction and Intention to Revisit. Primary and secondary data were obtained through interviews and filling out questionnaires with the Structural Equation Modeling (SEM) analysis method. The results of Partial Least Square (PLS) analysis show that farmer's capacity has a significant effect on tourists's satisfaction, which leads to tourists's intention to revisit. it is expected that higher capacity of agroutourism management among farmers will increase tourist's satisfaction which affects tourist's intention to revisit hence, improving the welfare of the community, especially farmers in Jatiluwih Agrotourism.
\end{abstract}

Keywords: Farmers' Capacity, Satisfaction, Revisit, PLS

\section{INTRODUCTION}

The agricultural sector has an important and strategic role in the development of the national economy. The agricultural sector has proven to be the most survive in the economic crisis and it http://ojs.unud.ac.id/index.php/eot opens awareness that the agricultural sector must continue to be strived as a basis for overcoming threats or crises and achieving national economic growth with full support from the government. The rapid development of 
tourism in Bali has impacted the development of other sectors, especially agriculture. The role of the agricultural sector is declining while the role of the tourism sector is increasing. To minimize leakage and negative impacts of tourism development, the development of tourism attractions is recommended to optimize the potential of Bali-based natural and cultural tourism attractions and be directed at natural tourism attractions such as agrotourism, ecotourism, marine tourism, and rural tourism (Wiranatha and Suryawardani, 2018).

Jatiluwih Agrotourism is one of the favorite destinations. This is what makes Jatiluwih included in the World Cultural Heritage Site (WBD) by UNESCO. In addition, Jatiluwih Agrotourism has a management body that officially manages matters related to it. Tourist visits are increasing but farmers are still considered as objects in agrotourism activities. In facts, the benefits of visits have not been fully enjoyed by farmers. Therefore, farmers' capacity needs to be developed to build potential benefits in increasing information and knowledge transfer (Badamas, 2009 in Veronice et al, 2008).

The capacity of farmers in managing agrotourism must always be improved and developed in order to http://ojs.unud.ac.id/index.php/eot achieve the expected goals. This capacity is reflected in the knowledge, attitudes and skills of farmers. In agrotourism management, farmers should be made the main subject or executor involved directly. With the high capacity of farmers in managing together with stakeholders, it is expected to be able to increase Tourists' satisfaction and have implications for increasing revisit intention to improve the welfare of the community, especially farmers in Jatiluwih Agrotourism.

Based on the description above, research on "Farmers' Capacity in the Management of Jatiluwih Agrotourism and Its Effect on Tourists' satisfaction and Revisit Intention" is very important to be carried out. With the high capacity of farmers in managing agrotourism, it is expected to increase Tourists' satisfaction and have implications for increasing revisit intention to improve the welfare of the community, especially farmers in Jatiluwih Agrotourism.

\section{Formulation of the problems}

Based on the background description above, the formulation of the problems is as follows:

1. What are the effects of the capacity of farmers on tourists' satisfaction in Jatiluwih Agrotourism? 
2. What are the effects of tourists' satisfaction on the revisit intention to Jatiluwih Agrotourism?

\section{Research Purposes}

The purposes of this research are:

1. Analyzing the capacity of farmers on Tourists' satisfaction in Jatiluwih Agrotourism.

2. Analyzing the effect of tourists' satisfaction on the revisit intention of tourists visiting Jatiluwih Agrotourism.

\section{Hypothesis}

Based on the previous description, seven research hypotheses are proposed so that the research objectives can be achieved, viz:

a. Hypothesis I

$\mathrm{H}_{0}$ : Farmers' knowledge does not significantly influence tourists' satisfaction.

$\mathrm{H}_{1}$ : Farmers' knowledge has a significant effect on tourists' satisfaction.

b. Hypothesis II

$\mathrm{H}_{0}$ : The attitude of farmers does not significantly influence tourists' satisfaction.

$\mathrm{H}_{2}$ : Farmers' attitudes significantly influence the management of tourist satisfaction.

http://ojs.unud.ac.id/index.php/eot c. Hypothesis III

$\mathrm{H}_{0}$ : Farmers' skills do not significantly influence tourists' satisfaction.

$\mathrm{H}_{3}$ : Farmers' skills significantly influence tourists' satisfaction.

\section{d. Hypothesis IV}

$\mathrm{H}_{0}$ : Tourists' satisfaction does not significantly influence tourists' revisit intention.

$\mathrm{H}_{4}$ : Tourists satisfaction has a significant effect on tourists' revisit intention.

\section{LITERATURE REVIEW}

\section{Farmers' Capacity}

Marliati (2008) defines the capacity of farmers as the power of farmers to run an ideal farm in accordance with the expected goals (better farming, better living, better business, and better environment). Suprayitno (2011) added that the level of capacity is related to knowledge, attitudes, and abilities in overcoming various problems faced by farmers in terms of technical, managerial, and social skills.

\section{Tourists' Satisfaction}

Kotler (2002) defines that Tourists' satisfaction is a feeling of pleasure or disappointment that arises from the results of comparing expectations with the reality experienced. In other words, that Tourists' satisfaction is a comparison between the 
performance of the products produced and the performance perceived by tourists. If it is below expectations, tourists are not satisfied. If performance meets expectations, tourists are satisfied. If the performance exceeds expectations, tourists are very satisfied.

\section{Revisit Intention}

According to Ferdinand (2011), intention to revisit is a behavior that arises as a response to objects that indicate the customer's desire to make a repeat purchase. Interest in repeat visits can also be interpreted as part of the visitor loyalty stage. Revisit intention is the desire and actions of customers to make a repeat visit because of the satisfaction received (Puspitasari, 2011).

\section{RESEARCH METHODS}

The research was conducted from May to October 2019 at Jatiluwih Agrotourism. This location determination was done purposively based on various certain considerations. The study was conducted with respondents of farmers and tourists in Jatiluwih Agrotourism using questionnaire and interview methods. Sampling using simple random sampling method and combined with accidental sampling method. The total sample was 100 respondents consisting of 50 farmers http://ojs.unud.ac.id/index.php/eot and 50 tourists. Analysis of data using the analysis of the Structural Equation Model (SEM) with the help of SmartPLS 3.0 software. The indicators used were 46 divided into five factors.

\section{Contribution of Stakeholders to the}

Jatiluwih Agrotourism Community

Contributions made by stakeholders in economic matters such as support surrounding the production of seeds, purchase of liquid and solid fertilizers, as well as land management were as much as 247 million rupiahs by the Government of Tabanan Regency. In addition, assistance such as solid fertilizers and irrigation improvements with irrigation improvement funds around 180 million rupiahs by the Provincial Government of Bali, and a special financial assistance fund (BKK) of 50 million rupiah. Of the revenue funds, operational management divides funds for agency operations $10 \%$, facility and infrastructure development 20\%, operational management $35 \%$, and villages and regional governments $35 \%$. Operational funds consist of $12.25 \%$ for operational needs such as office stationery. In addition, $5.25 \%$ for Corporate Social Responsibility (CSR) and $17.5 \%$ for wages to HR in Operational Management. The village and regional government funds 
consist of $15.75 \%$ for the regional government and $19.25 \%$ for the village and organization of the irrigation system of Subak. The village and subak funds consisted of $5.775 \%$ for the Jatiluwih Traditional Village, $4.8125 \%$ for the administrative village, $4.0425 \%$ for the Jatiluwih Subak, 3.85\% for the Gunungsari Customary Village, $0.385 \%$ for the Subak Abian Jatiluwih, and by $0,385 \%$ for Subak Abian Gunungsari. The contribution of the Operational Management of Jatiluwih Tourism Destination Region to Subak can be said to be unfavorable because farmers are only used as objects or supporters of tourism. This is evident from the number of payments given to subaks of only $4.8125 \%$ of $100 \%$ of total revenue funds.

The operational management of the Jatiluwih tourism area should make farmers as an important subject because the main object of agrotourism is terraced rice fields where farmers have a large role in the management of agrotourism. Based on this, the distribution of subsidized funds for subaks should be greater which will have an impact on the welfare of farmers' families. This is because farmers know more about the technical aspects of the field and environmental conditions in the village of Jatiluwih including the types of plants suitable for planting during certain seasons.
Contributions in terms of social life are reflected in the empowered community so that they are involved in the development of Jatiluwih Agrotourism. This is consistent with the results of research in the attitude factor of farmers (X2) on the indicator of farmers empowered in the development of agrotourism (SP6) that the average farmer answered strongly agreed. The environmental benefits are also reflected in the existence of a $3 R$ (reduce, reuse, recycle) Garbage Disposal Site (TPS) in Banjar Kesambahan Kelod and a rule that wastewater must not enter the irrigation channel so as not to pollute the rice fields. Promotion of the subak system in Bali was also carried out for example at the Majapahit International Travel Fair in Surabaya. The Jatiluwih tourism management agency also held the Jatiluwih Festival for the third time in September 2019. The series of events included a dance performance from the PKK women's organization of 400 people in front of the Pura Dewi Sri Subak Temple, a local culinary exhibition, camping and cultural camp (there is a traditional game involving 17 elementary and vocational schools). 


\section{RESULTS AND DISCUSSION}

\section{Characteristics of Respondents}

The study was conducted on 100 respondents, namely 50 farmers and 50 tourists. Respondent characteristics discussed in this study include gender, age, education level, and country of origin of tourists.

Table 1. Characteristics of Jatiluwih Agrotourism Respondents in 2019

\begin{tabular}{|c|c|c|c|c|c|}
\hline \multirow[t]{2}{*}{ No } & \multirow{2}{*}{$\begin{array}{l}\text { Charact } \\
\text { eristics }\end{array}$} & \multirow[t]{2}{*}{ Category } & \multicolumn{2}{|c|}{$\begin{array}{c}\text { Number of } \\
\text { people }\end{array}$} & \multirow{2}{*}{$\begin{array}{c}\text { Percent } \\
\text { age } \\
(\%)\end{array}$} \\
\hline & & & Farmers & Tourists & \\
\hline \multirow{4}{*}{1} & \multirow{4}{*}{ Age } & $\leq 15$ years old & & 3 & 1 \\
\hline & & $\begin{array}{c}16-25 \text { years } \\
\text { old }\end{array}$ & 1 & 16 & 17 \\
\hline & & $\begin{array}{c}26-55 \text { years } \\
\text { old }\end{array}$ & 20 & 28 & 48 \\
\hline & & $\geq 56$ years old & 29 & 3 & 32 \\
\hline \multirow{2}{*}{2} & \multirow{2}{*}{ Sex } & Male & 35 & 22 & 57 \\
\hline & & Female & 15 & 28 & 43 \\
\hline \multirow{4}{*}{3} & \multirow{4}{*}{$\begin{array}{c}\text { Level of } \\
\text { educatio } \\
n\end{array}$} & $\begin{array}{c}\text { Elementary } \\
\text { school }\end{array}$ & & 18 & 18 \\
\hline & & Middle School & 9 & 3 & 12 \\
\hline & & \begin{tabular}{|c|} 
High School / \\
Vocational \\
School \\
\end{tabular} & 12 & 6 & 18 \\
\hline & & $\begin{array}{c}\text { Diploma / } \\
\text { Bachelor } \\
\text { Degree } \\
\end{array}$ & 11 & 41 & 52 \\
\hline \multirow{8}{*}{4} & \multirow{8}{*}{$\begin{array}{l}\text { Country } \\
\text { of } \\
\text { origin }\end{array}$} & Indonesia & 50 & 18 & 68 \\
\hline & & France & & 12 & 12 \\
\hline & & The USA & & 4 & 4 \\
\hline & & Spain & & 4 & 4 \\
\hline & & Australia & & 2 & 2 \\
\hline & & Germany & & 2 & 2 \\
\hline & & Italy & & 2 & 2 \\
\hline & & etc & & 6 & 6 \\
\hline
\end{tabular}

\section{Outer Model Evaluation}

1. Validity test

a) Convergent Validity

i) Validity Indicator

The validity of convergence reflects the strength of the interlation between variables and their indicators. In Figure 1 (before being dropped) there are eleven indicators that have a loading factor value $<0.7$, that is, variable X1: PP3; PP8; PP9; PP10; PP11; X2: SP9; SP10; SP13; SP14, X3: KP6, and KP7. According to Chin (1998), the loading factor value below 0.7 must be dropped so that the PLS analysis is repeated. After re-analysis, the loading factor value of the whole indicator meets the convergence validity criteria. Figure of the model before dropping the indicator can be seen in Figure 1 while the model figure after dropping the indicators in Figure 1, can be seen in Figure 2.

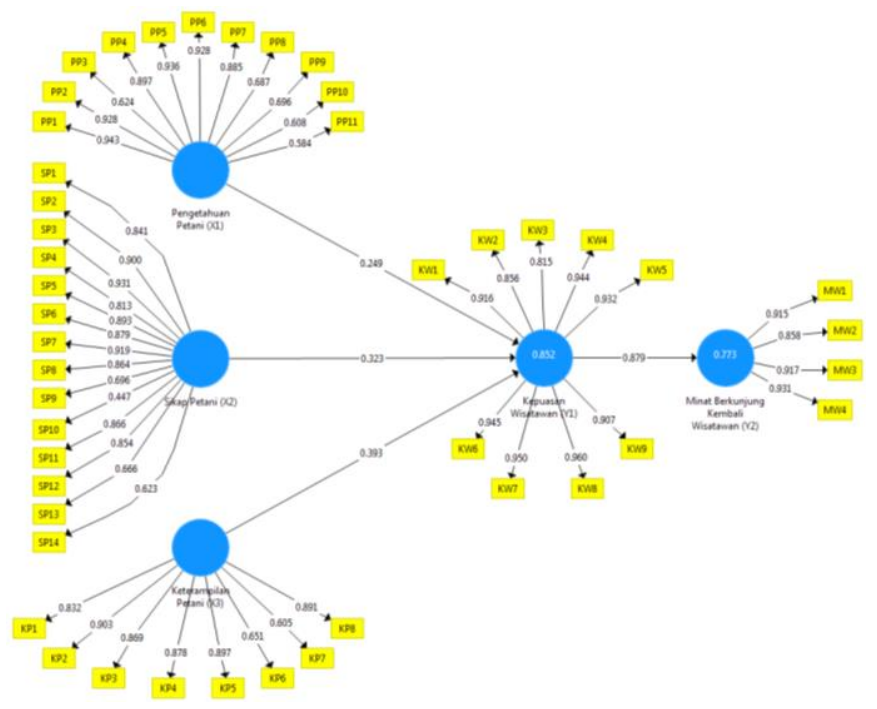

Figure 1. Initial Model 
Description of Figure 1

\section{Farmers' Knowledge (X1)}

PP1 : Farmers' knowledge in identifying potentials and utilizing opportunities for farming \& agrotourism (such as tracking and cycling)

PP2 : Farmers' knowledge in marketing elements of agricultural products to tourists (such as brown rice, brown rice tea, coffee, cocoa, and oranges)

PP3: Farmers' knowledge in souvenir marketing elements for tourists

PP4: Farmers' knowledge in supporting facilities and infrastructure

PP5: Farmers' knowledge in maintaining environmental security as part of the implementation of the 7 charm of the tourism sector

PP6: Farmers' knowledge in maintaining environmental comfort as part of the implementation of the Sapta charm of the tourism sector

PP7: Farmers' knowledge in controlling pests and plant diseases in agrotourism

PP8: Farmer's knowledge in managing agrotourism

PP9: Farmers' knowledge in the promotion of agrotourism

PP10: Farmers' knowledge in maintaining the sustainability of farming \& agrotourism resources and in pioneering $\&$ identifying the development of tourism potential http://ojs.unud.ac.id/index.php/eot
PP11: Mastering theoretical concepts in the field of agricultural knowledge and resources, agricultural development, agricultural science and technology in general and the theoretical concepts of special sections in the field of knowledge in depth.

\section{Farmers' Attitude (X2)}

SP1: Having the awareness to maintain a harmonious relationship with God Almighty

SP2: Have the obligation to do something for nature and humans as a respect for God Almighty

SP3: Attitudes of farmers in maintaining harmonious relations with the community, farmers, and tourists visiting Jatiluwih Agrotourism

SP4: Attitudes of farmers in providing aspirations / opinions in the development and management of community-based agrotourism

SP5: Farmers are involved and play an active role in the development of agrotourism

SP6: Farmers are empowered in developing agrotourism

SP7: Farmers are responsible for environmental preservation

SP8: Attitudes of farmers in participating in various trainings to realize agrotourism sustainability

SP9: Farmer's attitude towards cultural preservation of subak (SP9), 
SP10: Farmers give a positive interpretation of tourists visiting agrotourism so that tourists enjoy agrotourism attractions

SP11: Farmers' attitude in participating in environmental preservation ceremonies

SP12: Attitudes of farmers to the law and spatial regulations stipulated by the government

SP13: Farmers value local culture in agrotourism management

SP14: Farmers have a high commitment and are responsible for the sustainability of agrotourism

Farmers' Skills (X3)

KP1: Farmers' skills in agrotourism development training

KP2: Farmers' skills in implementing tradition and culture

KP3: Farmers' skills in protecting the environment

KP4: Farmers' skills in developing community-based agrotourism

KP5: Farmers' skills in improving the ability to manage agrotourism businesses

KP6: Farmers' skills in training in making crafts and souvenirs for visitors

KP7: Farmers' skills in improving communication skills with tourists

KP8: Farmers' skills in maintaining sustainable agrotourism

\section{Tourists' Satisfaction (Y1)}

KW1: Tourists' satisfaction for services obtained at Jatiluwih Agrotourism

KW2: Tourists' satisfaction of food and drinks served at restaurants in Jatiluwih Agrotourism

KW3: Tourists' satisfaction on handicrafts sold at Jatiluwih Agrotourism

KW4: Tourists' satisfaction for safety and comfort in Jatiluwih Agrotourism

KW5: Tourists' satisfaction at Jatiluwih Agrotourism attractions such as tracking and cycling

KW6: Tourists' satisfaction in the hospitality of farmers and Jatiluwih people

KW7: Tourists' satisfaction on agricultural products marketed in Jatiluwih Agrotourism (such as brown rice and brown rice tea)

KW8: Tourists' satisfaction in enjoying the beauty of rice terraces in Jatiluwih

KW9: Tourists' satisfaction on all activities in Jatiluwih.

\section{Revisit Intention (Y2)}

MW1: Tourists' interest in revisit intention to Jatiluwih Agrotourism

MW2: Promoting Jatiluwih Agrotourism to friends and relatives

MW3: Recommend Jatiluwih Agrotourism to friends and relatives 
MW4: Making Jatiluwih Agrotourism the first choice for the next vacation.

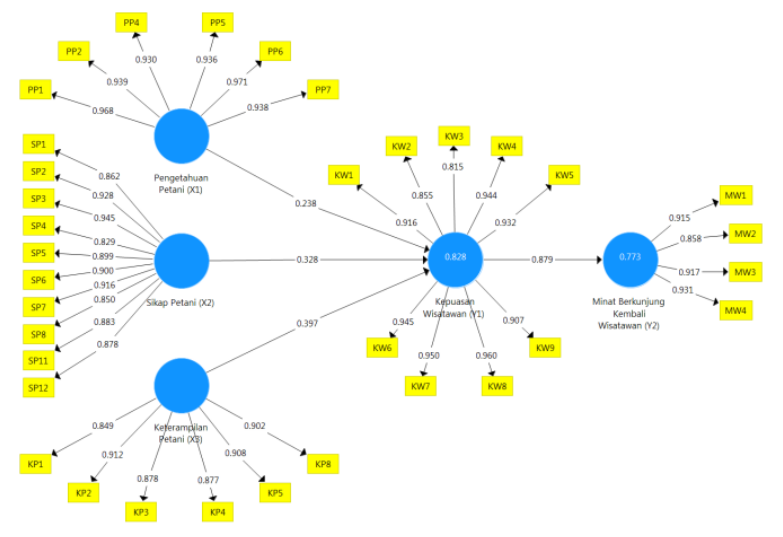

Figure 2. Final Model

Table 3. Evaluation of Outer Models

\begin{tabular}{lccc}
\hline Variable & $\begin{array}{c}\text { Composite } \\
\text { Reliability }\end{array}$ & $\begin{array}{c}\text { Cronbach's } \\
\text { Alpha }\end{array}$ & AVE \\
\hline X1 & 0,981 & 0,977 & 0,897 \\
X2 & 0.971 & 0,974 & 0,791 \\
X3 & 0,946 & 0,957 & 0,789 \\
Y1 & 0,975 & 0,979 & 0,837 \\
Y2 & 0,927 & 0,948 & 0,820 \\
\hline
\end{tabular}

ii) Factor of Reliability

Based on the results of the study in Table 3 the value of Cronbach's alpha on all factors is more than 0.7. This shows that the factors are said to be reliable.

iii) Value of AVE

In Table 3, you can see the AVE value of all factors above 0.5 . This shows that the factors are able to explain more than half the variants derived from the indicators.

\section{b. Discriminant Validity}

The discriminant validity evaluation was carried out in two stages, namely by looking at the cross loading value and comparing the root of the AVE value. i) Cross Loading Value

Table 4. Cross Loading Value

\begin{tabular}{llllll}
\hline & X1 & X2 & X3 & Y1 & Y2 \\
\hline PP1 & $\mathbf{0 , 9 6 8}$ & 0,811 & 0,811 & 0,763 & 0,652 \\
PP2 & $\mathbf{0 , 9 3 9}$ & 0,871 & 0,7871 & 0,838 & 0,678 \\
PP4 & $\mathbf{0 , 9 3 0}$ & 0,769 & 0,769 & 0,741 & 0,653 \\
PP5 & $\mathbf{0 , 9 3 6}$ & 0,862 & 0,862 & 0,837 & 0,716 \\
PP6 & $\mathbf{0 , 9 7 1}$ & 0,787 & 0,787 & 0,748 & 0,619 \\
PP7 & $\mathbf{0 , 9 3 8}$ & 0,738 & 0,738 & 0,700 & 0,603 \\
SP1 & 0,650 & $\mathbf{0 , 8 6 2}$ & 0,830 & 0,753 & 0,674 \\
SP2 & 0,751 & $\mathbf{0 , 9 2 8}$ & 0,842 & 0,783 & 0,675 \\
SP3 & 0,815 & $\mathbf{0 , 9 4 5}$ & 0,816 & 0,842 & 0,764 \\
SP4 & 0,723 & $\mathbf{0 , 8 2 9}$ & 0,679 & 0,715 & 0,707 \\
SP5 & 0,820 & $\mathbf{0 , 8 9 9}$ & 0,731 & 0,825 & 0,703 \\
SP6 & 0,741 & $\mathbf{0 , 9 0 0}$ & 0,817 & 0,765 & 0,661 \\
SP7 & 0,825 & $\mathbf{0 , 9 1 6}$ & 0,816 & 0,880 & 0,704 \\
SP8 & 0,781 & $\mathbf{0 , 8 5 0}$ & 0,769 & 0,826 & 0,631 \\
SP11 & 0,737 & $\mathbf{0 , 8 8 3}$ & 0,782 & 0,722 & 0,712 \\
SP12 & 0,737 & $\mathbf{0 , 8 7 8}$ & 0,793 & 0,700 & 0,667 \\
KP1 & 0,680 & 0,759 & $\mathbf{0 , 8 4 9}$ & 0,796 & 0,743 \\
KP2 & 0,708 & 0,811 & $\mathbf{0 , 9 1 2}$ & 0,764 & 0,711 \\
KP3 & 0,704 & 0,819 & $\mathbf{0 , 8 7 8}$ & 0,803 & 0,757 \\
KP4 & 0,478 & 0,684 & $\mathbf{0 , 8 7 7}$ & 0,658 & 0,694 \\
KP5 & 0,658 & 0,800 & $\mathbf{0 , 9 0 8}$ & 0,767 & 0,720 \\
KP8 & 0,756 & 0,813 & $\mathbf{0 , 9 0 2}$ & 0,806 & 0,803 \\
KW1 & 0,742 & 0,817 & 0,794 & $\mathbf{0 , 9 1 6}$ & 0,773 \\
KW2 & 0,584 & 0,727 & 0,762 & $\mathbf{0 , 8 5 5}$ & 0,693 \\
KW3 & 0,764 & 0,759 & 0,713 & $\mathbf{0 , 8 1 5}$ & 0,752 \\
KW4 & 0,775 & 0,809 & 0,771 & $\mathbf{0 , 9 4 4}$ & 0,819 \\
KW5 & 0,756 & 0,825 & 0,869 & $\mathbf{0 , 9 3 2}$ & 0,812 \\
KW6 & 0,765 & 0,801 & 0,825 & $\mathbf{0 , 9 4 5}$ & 0,852 \\
KW7 & 0,770 & 0,819 & 0,786 & $\mathbf{0 , 9 5 0}$ & 0,833 \\
KW8 & 0,780 & 0,831 & 0,836 & $\mathbf{0 , 9 6 0}$ & 0,890 \\
KW9 & 0,782 & 0,868 & 0,771 & $\mathbf{0 , 9 0 7}$ & 0,802 \\
MW1 & 0,660 & 0,775 & 0,768 & 0,802 & $\mathbf{0 , 9 1 5}$ \\
MW2 & 0,461 & 0,532 & 0,647 & 0,643 & $\mathbf{0 , 8 5 8}$ \\
MW3 & 0,563 & 0,612 & 0,736 & 0,779 & $\mathbf{0 , 9 1 7}$ \\
MW4 & 0,774 & 0,842 & 0,842 & 0,922 & $\mathbf{0 , 9 3 1}$ \\
\hline & & & & &
\end{tabular}

\section{ii) Root Value of AVE}

Based on Table 5, each AVE root value is greater than the correlation between factors and other factors. This shows that all latent factors have good validity. 
Table 5. AVE Roots and Correlations

\begin{tabular}{cccccccc}
\hline Factors & AVE & $\sqrt{\text { AVE }}$ & Y1 & X3 & Y2 & X1 & X2 \\
\hline Y1 & 0,837 & 0,915 & $\mathbf{0 , 9 1 5}$ & & & & \\
X3 & 0,789 & 0,888 & 0,866 & $\mathbf{0 , 8 8 8}$ & & & \\
Y2 & 0,820 & 0,905 & 0,879 & 0,833 & $\mathbf{0 , 9 0 6}$ & & \\
X1 & 0,897 & 0,947 & 0,818 & 0,754 & 0,692 & $\mathbf{0 , 9 4 7}$ & \\
X2 & 0,791 & 0,890 & 0,882 & 0,883 & 0,776 & 0,855 & $\mathbf{0 , 8 9 0}$ \\
\hline
\end{tabular}

\section{Reliability Test}

Based on Table 3, the composite reliability value of all factors has a value greater than the required standard value of 0.70 . This shows there is stability and consistency of internal indicators.

\section{Inner Model Evaluation}

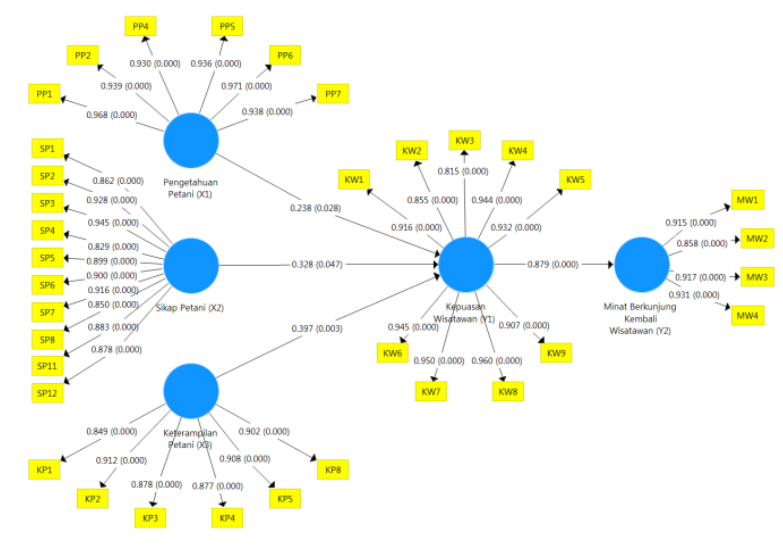

Figure 3. Structural Equation Model based on Smart PLS Version 3.0.

The model in this study is aimed at looking at the capacity of farmers towards tourist satisfaction and revisit intention that is modeled through the structural equation model (SEM) to obtain the best model. In this model, it involves five latent variables: farmers 'knowledge is reflected by 6 indicators, farmers' attitudes are http://ojs.unud.ac.id/index.php/eot reflected by 10 indicators, farmers 'skills are reflected by 6 indicators, tourist satisfaction is reflected by 9 indicators, and tourists' revisit intention is reflected by 4 indicators. Based on the model framework and this research hypothesis, the structural equation model can be seen in Figure 3.

\section{GoF Test}

The feasibility of a structural equation model, in its entirety, was carried out by calculating the value of Goodness of Fit (GoF) using the following formula (Tenenhaus et.al, 2005 in Suryawardani, 2018):

$$
\begin{gathered}
\mathrm{GoF}=\sqrt{\text { Communality } \times R^{2}}= \\
\sqrt{\overline{A V E} \times \overline{R^{2}}}
\end{gathered}
$$

Using this formula, the GoF of the model is calculated at 0.813 . This shows that the model can be accepted and interpreted.

Table 6. Model Fit

\begin{tabular}{ccc}
\hline & $\begin{array}{c}\text { Saturated } \\
\text { Model }\end{array}$ & $\begin{array}{c}\text { Estimated } \\
\text { Model }\end{array}$ \\
\hline SRMR & 0,072 & 0,073 \\
Chin- & $1.230,537$ & $1.235,711$ \\
Square & & \\
NFI & 0,645 & 0,652 \\
\hline
\end{tabular}

2. Path coefficients

Table 7. Path Coefficients

\begin{tabular}{ccccc}
\hline Path & $\begin{array}{c}\text { Original } \\
\text { Sampel }\end{array}$ & $\begin{array}{c}\text { Sampel } \\
\text { Mean }\end{array}$ & $\begin{array}{c}\text { Standard } \\
\text { Deviation } \\
\text { (STDEV) }\end{array}$ & $\begin{array}{c}\text { P- } \\
\text { value }\end{array}$ \\
\hline $\mathrm{X} 1 \rightarrow \mathrm{Y} 1$ & 0,238 & 0,240 & 0,106 & $\begin{array}{c}0,02 \\
6\end{array}$ \\
$\mathrm{X} 2 \rightarrow \mathrm{Y} 1$ & 0,328 & 0,303 & 0,157 & $\begin{array}{c}0,03 \\
7\end{array}$ \\
$\mathrm{X} 3 \rightarrow \mathrm{Y} 1$ & 0,397 & 0,414 & 0,128 & $\begin{array}{c}0,00 \\
2\end{array}$ \\
$\mathrm{Y} 1 \rightarrow \mathrm{Y} 2$ & 0,879 & 0,879 & 0,038 & 0,00 \\
0
\end{tabular}


3. Test of $R^{2}$

\begin{tabular}{ccc}
\multicolumn{3}{c}{ Table $8 . \mathrm{R}^{2}$ values } \\
\hline Factors & $\mathrm{R}^{2}$ & $\mathrm{R}^{2}$ Adjusted \\
\hline Tourist & 0,828 & 0,817 \\
$\begin{array}{c}\text { Satisfaction (Y1) } \\
\text { Revisit Intention } \\
\text { (Y2) }\end{array}$ & 0,773 & 0,769 \\
\hline
\end{tabular}

Based on Table 8, it can be seen that the $\mathrm{R}^{2}$ value of tourist satisfaction variable is 0.828 . This means that $82.8 \%$ of tourist satisfaction variables can be explained by farmers' knowledge, farmers' attitudes, farmers' skills and the remaining $17.2 \%$ is explained by other variables outside the research model. $\mathrm{R}^{2}$ value of tourist revisit intention variable is 0.773 , meaning that the revisit intention variable of $77.3 \%$ can be explained by tourist satisfaction and the remaining $22.7 \%$ is explained by variables outside the research model. The value of $\mathrm{R}^{2}$ on the variable of tourist satisfaction and tourist revisit intention has a strong predictive power because the value of $\mathrm{R}^{2}$ is above 0.75 (Henseller et.al., 2009 in Santoso, 2018).

\section{DISCUSSION}

\section{The Effects of Farmers' Capacity on Tourists' Satisfaction in Jatiluwih Agrotourism}

The effects of farmers' capacity on tourists' satisfaction in Jatiluwih Agrotourism are discussed in three sections as follows:

http://ojs.unud.ac.id/index.php/eot
1. Effects of Farmers' Knowledge on Tourists' Satisfaction

The results of testing the first hypothesis showed that the relationship between farmers' knowledge factor (X1) and tourist satisfaction (Y1) showed the Original Sample $(\mathrm{O})$ value of 0.238 and $\mathrm{P}$ value of $0.026<0.05$, then $\mathrm{H}_{0}$ was rejected. Based on the results of data processing, it can be concluded that the knowledge of farmers (X1) significantly influences tourist satisfaction (Y1), meaning that the knowledge of farmers with their indicators significantly influences tourists' satisfaction factors.

The most significant indicator contributing to this factor is the knowledge of farmers in maintaining environmental comfort as part of the implementation of the Sapta / seven-charm program in the tourism sector with a loading factor of 0.971 and a P-value of 0.026 . In addition, the indicators that have the lowest significant value are farmers' knowledge in supporting facilities and infrastructure with a loading factor value of 0.930 and a Pvalue of 0.026 .

2. The Effects of Farmers' Attitude on Tourists' Satisfaction

The second hypothesis testing results show that the relationship between farmers' attitude factor (X2) and tourists' satisfaction (Y1) shows the Original 
Sample (O) value of 0.328 and the P-value of $0.037<0.05$, then $\mathrm{H}_{0}$ was rejected. Based on the results of data processing, it can be concluded that the attitude of farmers (X2) significantly influences tourists' satisfaction (Y1). This means that in this study the attitude of farmers with their indicators significantly influences tourists' satisfaction factors.

The most significant indicator contributing to this factor is the attitude of farmers in maintaining a harmonious relationship with the community, farmers, and tourists visiting Jatiluwih Agrotourism with a loading factor of 0.945 and a Pvalue of 0.037 . In addition, the indicator that has the lowest significant value is the attitude of farmers in providing aspirations / opinions in the development and management of community-based agrotourism with a loading factor of 0.829 and a P-value of 0.037 .

\section{Effects of Farmers' Skills on Tourists'} Satisfaction

The results of testing the third hypothesis showed that the relationship between farmers' skill factors (X3) and tourists' satisfaction (Y1) showed the Original Sample (O) value of 0.397 and the P-value of $0.002<0.05$, then $\mathrm{H}_{0}$ was rejected. Based on the results of data processing, it can be concluded that the skills of farmers (X3) have a significant http://ojs.unud.ac.id/index.php/eot relationship to tourists' satisfaction (Y1). This means that in this study, the skills of farmers and their indicators significantly influence tourists' satisfaction factors.

The most significant indicator contributing to this factor is farmers' skills in carrying out traditions and culture with a loading factor value of 0.912 and a Pvalue of 0.002 . In addition, the indicator that has the lowest significant value is farmers' skills in agrotourism development training with a loading factor of 0.849 and a P-value of 0.002 .

\section{The Effects of Tourists' Satisfaction on Revisit Intention of Tourists}

The fourth hypothesis testing results indicate that the relationship of tourists' satisfaction factor (Y1) with the revisit intention of tourists (Y2) shows the Original Sample (O) value of 0.879 and the P-value of $0.000<0.05$, then $\mathrm{H}_{0}$ was rejected. Based on the results of data processing, it can be concluded that tourists' satisfaction has a significant relationship to the revisit intention of tourists, meaning that in this study, tourists' satisfaction factors with their indicators influence the factors of revisit intention significantly. This is in accordance with the research of Alit Purnami (2018) which states that tourists' 
satisfaction has a significant effect on the revisit intention.

Among the nine variables, the variable that has the biggest loading factor value is satisfaction, which is reflected in enjoying the beauty of the terraced rice fields in Jatiluwih with a loading factor value of 0.960 and a P-value of 0,000 . In addition, the indicator that has the lowest significant value is the satisfaction of tourists in handicrafts sold at Jatiluwih Agrotourism with a loading factor of 0.815 and a P-value of 0,000 .

\section{CLOSING}

Based on the results and discussions that have been carried out in this research, it can be concluded: (1) The capacity of farmers has a significant influence on tourists' satisfaction in Jatiluwih Agrotourism: a) Farmers' knowledge has a significant effect on the satisfaction of Jatiluwih Agrotourism tourists. b) Farmers' attitudes significantly influence the satisfaction of Jatiluwih Agrotourism. c) Farmers' skills significantly influence the satisfaction of Jatiluwih Agrotourism and (2) Tourists' satisfaction significantly influences the revisit intention of tourists to Jatiluwih Agrotourism.

http://ojs.unud.ac.id/index.php/eot
Based on the results of the discussion and conclusions obtained from this study, a number of suggestions are made as follows: (1) The availability of facilities and infrastructure support from stakeholders should be given more comprehensively and clearly announced to each farmer or subak's member in order to increase farmers' knowledge in Jatiluwih Agrotourism . (2) Meetings or discussions held in the development and management of Jatiluwih Agrotourism should be more motivating for the intention of every farmer or subak's member to improve the attitude of the farmers. Women farmers need to be encouraged to participate and every aspiration / opinion given by the participants' present needs to be accounted for by the stakeholders. (3) Agrotourism development training needs to encourage each subak member and especially farmers aged $\geq 56$ years old so that they have improved skills. In addition, the budget and intensity in agrotourism development training needs to be increased. Diversity of training that needs to be held such as postharvest training, pest and disease control, and tourist assistance training for farmers. (4) Crafts that are sold need variations in type, product quality, and packaging must be improved in order to increase the satisfaction and revisit intention of tourists to Jatiluwih Agrotourism. Craft products sold must also 
represent Jatiluwih Agrotourism. In addition, the management body should have information about explaining the life cycle of rice and how it is processed from land preparation to postharvest so that tourists, especially from foreign countries, receive complete and clear information about the commodity.

\section{REFERENCES}

Ferdinand A. T. dan A. N. 2011 Analisis Pengaruh Kualitas Produk dan Kualitas Pelayanan terhadap Kepuasan Pelanggan untuk Mendorong Minat Beli Ulang (studi pada Pengguna Nokia Semarang). Semarang: Universitas Dipenogoro.

Kotler, Philip. 2002. Marketing Management (Millenium Edition). Jakarta: Pearson Education and Prehanllindo.

Marliati, Sumardjo, Asngari PS, Tjitropranoto P, Saefuddin A. 2008. Faktor-Faktor Penentu Peningkatan Kinerja Penyuluh Pertanian dalam Memberdayakan Petani (Kasus di Kabupaten Kampar Provinsi Riau). Jurnal Penyuluhan. 4 (2): 92-99.

Purnami, A., and I G.A.O Suryawardani. 2018. The effect of the Quality Services on the Visitors' Satisfaction and Desire to Pay a Revisit to the Bali Pulina Agrotourism. E-Journal Of Tourism. 5(2): pp 62-71.

Puspitasari, A. N. 2011. Analisis Pengaruh Kualitas Produk dan Kualitas Pelayanan terhadap Kepuasan Pelanggan untuk Mendorong Minat Beli Ulang. Univeristas Dipenogoro. Semarang.
Santosa, Paulus Insap. 2018. Metode Penelitian Kuantitatif (Pengembanganan Hipotesis dan Pengujiannya Menggunakan SmartPLS). Yogyakarta: Andi.

Suprayitno, A. 2011. Model Peningkatan Partisipasi Petani Sekitar Hutan Dalam Mengelola Hutan Kemiri Rakyat: Kasus Pengelolaan Hutan Kemiri Kawasan Pegunungan Bulusaurang Kabupaten Maros Sulawesi Selatan. [Desertasi]. Bogor. Sekolah Pascasarjana Institut Pertanian Bogor.

Suryawardani, I. G. A. O. 2018. Evaluation of Marketing Strategy of Sanur Village Festival Based on Visitors' Behaviour. International Journal of Applied Business and Economic Ressearch, Vol 16 Number 2, 2018, page 216-276. ISSN 0972-7302.

Veronice, Helmi, Henmaidi, dan Ernita Arif. 2008. "Pengembangan Kapasitas dan kelembagaan Petani Kecil di Kawasan Pertanian melalui Pendekatan Manajemen Pengetahuan." Jurnal of Applied Agricultural Science and Technology. Vol 2 (2): 1-10.

Wiranatha, A.S., I G.A.O., Suryawardani, dan I K.G Bendesa. 2018. Model of Foreign Tourist's Loyalty in Cultural and Heritage Tourism. Journal of Global Stochastics Analysis.

Wiranatha, A.S., I G.A.O., Suryawardani, I K.G Bendesa dan M. Antara. 2018. Model of Foreign Tourist's Loyalty on Marine Tourism to Visit Bali. International Journal of Multidisciplinary Educational Research, Volume 5, Issue 3 (2), 2016. 